\title{
Fødselsinduksjon ved intrauterin veksthemming?
}

\begin{abstract}
Ved mistanke om intrauterin veksthemming nær termin er utfallet for mor og barn etter fødselsinduksjon i gjennomsnitt det samme som ved fødsel etter vanlig svangerskapsoppfølging.
\end{abstract}

Ved intrauterin veksthemming induseres ofte fødselen for å redusere risikoen for neonatal morbiditet og dødfødsel. Nå har nederlandske og engelske forskere sammenliknet effekten av fødselsinduksjon med svangerskapskontroll ved intrauterin vekstrestriksjon nær termin (1).

321 gravide ( $>36$ uker, enkeltsvangerskap) ble randomisert til induksjon av fødsel eller til videre tett oppfølging av svangerskapet. Barna i induksjonsgruppen ble født $\mathrm{i}$ gjennomsnitt ti dager tidligere enn barna i den andre gruppen. 5,3\% i induksjonsgruppen opplevde sammensatt alvorlig neonatalt utfall, mot 6,1\% i kontrollgruppen. Keisersnitt ble gjort hos henholdsvis $14,0 \%$ og $13,7 \%$ av mødrene.

- Denne studien er viktig, sier professor Anne Eskild ved Kvinneklinikken, Akershus universitetssykehus. - Det var ingen tilfeller av fosterdød eller død kort tid etter fødselen i noen av gruppene, men studien hadde begrenset statistisk styrke. Det må svært mange induksjoner til for å forebygge ett intrauterint dødsfall, hvis det i det hele tatt er noen effekt, sier hun.

- Barna i induksjonsgruppen veide i gjennomsnitt $130 \mathrm{~g}$ mindre enn barna i gruppen der fødselen ikke ble indusert.
Fødselsvekt er inverst knyttet til både cerebral parese og nedsatt hørsel hos barnet. Derfor kan det hende at veksthemmede barn har godt av å være i mors liv lenger for å forebygge sykelighet. Studien reiser mange nye og viktige spørsmål, ikke minst knyttet til presisjon av diagnostikken av intrauterin veksthemming i klinisk praksis, sier Eskild.

\section{Trine B. Haugen \\ trine.b.haugen@hf.hio.no \\ Tidsskriftet \\ Litteratur \\ 1. Boers KE, Vijgen SM, Bijlenga D et al. Induction versus expectant monitoring for intrauterine growth restriction at term: randomised equi- valence trial (DIGITAT). BMJ 2010; 341: c7087.}

\section{Langvarig behandling med lokalsteroid mot atopisk eksem}

Langvarig proaktiv antiinflammatorisk behandling kan forhindre nye utbrudd av atopisk eksem, ifølge en systematisk oversiktsartikkel (Br J Dermatol 2011; 164: 415-28).

Studiene var dobbeltblindede, placebokontrollerte og randomiserte og besto av en initial behandlingsstabiliserende fase for å indusere remisjon, etterfulgt av en proaktiv behandlingsfase for å forhindre nye utbrudd.

Flutikasonpropionat forhindret nye utbrudd $(R R 0,46)$ mer effektivt enn takrolimus (RR 0,78).

\section{Meningokokkbærertilstand ses oftest hos tenåringer}

Alder er den viktigste faktor for bærertilstand av Neisseria meningitidis, og bærerfrekvensen er høyest hos 19-åriger, trolig pga. deres kontaktmønster og sosiale atferd. Den hyppige forekomsten i denne aldersgruppen kan ha betydning for fremtidige vaksinasjonsstrategier.

For å vurdere bærertilstanden i alle aldersgrupper ble det utført en metaanalyse med 89 studier fra europeiske land eller land med samme epidemiologiske mønster, dvs. at sykdom hyppigst skyldes serogruppene B og C (Lancet Infect Dis 2010; 10: 853-61). Til den kvantitative datasyntesen brukte man data fra 82 artikler med i alt 143000 individuelle prøver.

Prevalensen av bærertilstand økte gjennom barndommen - fra 4,5\% hos småbarn til et maksimum på 23,7 \% hos 19-åringer. Så var det igjen et fall gjennom voksenalderen til 7-8\% hos 50-åringer.

\section{Stor nedgang i fosterdød}

\section{I slutten av 1960-årene døde nesten 1000 barn i mors liv etter 16. svan- gerskapsuke. Nå er tallet redusert til mellom 200 og 300. Det viser en ny norsk studie.}

Vi har analysert data fra Medisinsk fødselsregister over alle svangerskap etter 16 . svangerskapsuke i årene 1967-2006 (1). Studien omfattet nesten 2,2 millioner svangerskap. Endringer i fosterdød siden 1967-71 ble beregnet i rater og relativ risiko for svangerskapsuke 16-22, 23-29, $30-36$ og 37-43.

Det var en betydelig nedgang $i$ forekomsten av fosterdød (1). Den største nedgangen gjaldt tiden etter svangerskapsuke 37 , hvor fosterdødsraten er redusert med over $70 \%$, fra 10,8 tilfeller per 1000 pågåendegraviditeter til 3,3 per 1000 . Forekomsten av fosterdød mellom svangerskapsuke 16 og svangerskapsuke 22 økte, fra 1,7 til 3,4 per 1000 pågående graviditeter. Reduksjonen endret seg minimalt ved justering for mors og fars alder, antall tidligere fødsler, flerlingfødsler og svangerskapsforgiftning.

Årsaken til økt fosterdød i svangerskapsuke 16-22 kan være bedret rapportering til Medisinsk fødselsregistereller en reell økning. Vi tror at det har vært en reell $ø$ kning, og at økningen kan skyldes at flere gravide kvinner har fătt fjernet en del av livmorhalsen pga. celle-

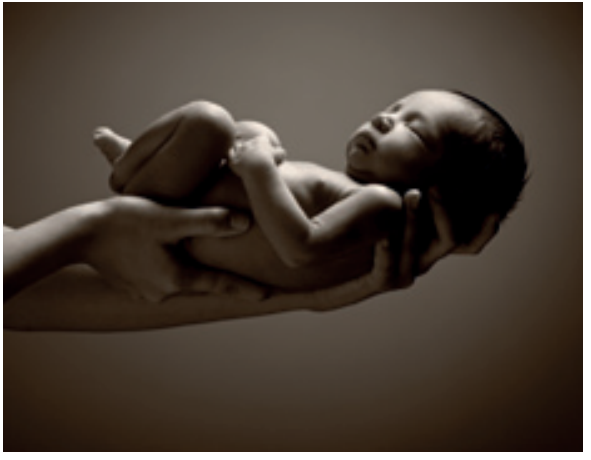

Illustrasjonsfoto Istockphoto

forandringer. Slik behandling gjøres for å forebygge livmorhalskreft, men øker samtidig risikoen for tidlig fødsel.

Nedgangen i fosterdød etter svangerskapsuke 22 skyldes sannsynligvis forbedringer i svangerskapsomsorgen og fødselshjelpen. Introduksjon av moderne teknologi i svangerskapsomsorgen har ført til mer presis beregning av termin og bedre diagnostikk av patologiske svangerskap.

\section{Aahshi Sarfraz}

aahshi.sarfraz@ahus.no

Kvinneklinikken

Akershus universitetssykehus

Litteratur

1. Sarfraz AA, Samuelsen SO, Eskild A. Changes in fetal death during 40 years - different trends for different gestational ages: a population based study in Norway. BJOG 2010; doi: 10.1111/ j.1471-0528.2010.02819.x. 